\title{
Substrate Properties of 25-nt Parallel-Stranded Linear DNA Duplexes
}

\author{
Karsten Rippe and Thomas M. Jovin* \\ Department of Molecular Biology, Max Planck Institute for Biophysical Chemistry, Postfach 2841, D-3400 Göttingen, FRG \\ Received April 12, 1989; Revised Manuscript Received July 12, 1989
}

\begin{abstract}
Four 25-nt oligonucleotides consisting of sequences of dA and dT (D1-4) have been synthesized. As shown in a companion paper (Rippe et al., 1989), the two combinations D1.D3 and D2.D4 form normal antiparallel duplexes, whereas the pairs D1·D2 and D3.D4 constitute duplexes with the same sequences, but with the two strands parallel to each other. The activities of the following DNA processing enzymes and chemical reagents on the parallel stranded (ps) and antiparallel stranded (aps) duplexes were tested. (i) The restriction endonucleases $D r a \mathrm{I}, S s p \mathrm{I}$, and $\mathrm{MseI}$ do not cut the ps duplexes. (ii) DNase I and exonuclease III exhibit a much lower activity with the ps duplexes. (iii) The nuclease activities of $S 1$ nuclease, micrococcal nuclease (S 7), phage $\lambda 5^{\prime}$-exonuclease, and the $3^{\prime}-5^{\prime}$ nuclease activity of Escherichia coli DNA polymerase I and its large fragment are higher with the ps than with the aps substrates. (iv) Bal 31 nuclease and the chemical nuclease 1,10-phenanthroline-copper ion [(OP) $\left.{ }_{2} \mathrm{Cu}^{+}\right]$degrade ps-DNA and aps-DNA at approximately the same rate but show preferred cutting sites only with the aps molecules. (v) The iron(II)-EDTA complex has equivalent nuclease activities with the ps and the aps molecules. (vi) The ps duplex is not a substrate for blunt-end ligation with phage T4 DNA ligase.
\end{abstract}

$\mathbf{P}_{\mathrm{h}}$ hysicochemical studies have demonstrated that given an appropriate selection of sequences two oligonucleotides will form parallel-stranded DNA duplexes instead of the conventional antiparallel B-DNA structure (Ramsing \& Jovin, 1988; Germann et al., 1988; Rippe et al., 1989). Parallel-stranded DNA has distinctive spectroscopic properties and a thermodynamic stability only slightly less than that of normal B-DNA (Ramsing et al., 1989). Besides the parallel orientation of the two constituent strands, the structural feature of note is the reverse Watson-Crick base pairing between $\mathrm{dA}$ and dT residues of the two constituent strands (Pattabiraman, 1986; van de Sande et al., 1988). Although direct confirmation of the ps ${ }^{1}$-DNA structure by crystallographic and ${ }^{1} \mathrm{H}$ NMR techniques is still not available, the experimental results presented to date are compatible with expectation. Thus, for example, the pattern of chemical methylation by dimethyl sulfate was the same for ps and aps hairpin molecules (van de Sande et al., 1988), excluding the existence of the Hoogsteen base pairs observed with other DNA structures involving parallelstranded interactions.

An assessment of the biological relevance of ps-DNA requires the evaluation of its interactions with proteins and other reagents with known specificities for certain DNA conformations. To pursue this point, we synthesized and characterized (Rippe et al., 1989) a set of four 25-nt oligonucleotides selected so as to form two pairs of ps and aps duplexes. These molecules were radiolabeled at the $5^{\prime}$ ends with ${ }^{32} \mathrm{P}$ and evaluated as substrates for a number of DNA-dependent enzymes and chemical nucleases.

\section{Materials AND METHODS}

Oligonucleotide Synthesis and End Labeling. Oligonucleotides D1-4 were synthesized and end labeled with ${ }^{32} \mathrm{P}$ as described elsewhere (Rippe et al., 1989).

Reaction Conditions. For the enzymatic and chemical nuclease reactions the samples were incubated at $25^{\circ} \mathrm{C}$, unless

\footnotetext{
* To whom correspondence should be addressed.

'Work done as part of the Diplom degree, awarded by the University of Göttingen, FRG.
}

otherwise indicated, and for specified time intervals in the following buffers.

(i) Restriction Endonucleases: DraI (Pharmacia), $10 \mathrm{mM}$ Tris- $\mathrm{HCl}, \mathrm{pH} 7.5,25 \mathrm{mM} \mathrm{NaCl}, 10 \mathrm{mM} \mathrm{MgCl}$, and $1 \mathrm{mM}$ 2-mercaptoethanol. $M \mathrm{seI}$ (New England Biolabs), $10 \mathrm{mM}$ Tris- $\mathrm{HCl}, \mathrm{pH} 7.5,50 \mathrm{mM} \mathrm{NaCl}, 10 \mathrm{mM} \mathrm{MgCl}, 10 \mathrm{mM}$ 2-mercaptoethanol, and $0.1 \mathrm{mg} \mathrm{mL}^{-1}$ BSA. SspI (Boehringer), $50 \mathrm{mM}$ Tris- $\mathrm{HCl}, \mathrm{pH} 7.5,0.1 \mathrm{M} \mathrm{NaCl}, 10 \mathrm{mM} \mathrm{MgCl}_{2}$, and 1 mM DTT.

(ii) Other Nucleases: Bovine pancreatic DNase I (Cooper Biomedicals), $40 \mathrm{mM}$ Tris- $\mathrm{HCl}, \mathrm{pH} 7.5,3.3 \mathrm{mM} \mathrm{MgCl}$, and $0.2 \mathrm{mM} \mathrm{CaCl}$. Escherichia coli exonuclease III (New England Biolabs), $50 \mathrm{mM}$ Tris- $\mathrm{HCl}, \mathrm{pH} 8.0,5 \mathrm{mM} \mathrm{MgCl}$, and $10 \mathrm{mM} 2$-mercaptoethanol. Alteromonas espejiani Bal 31 nuclease (GIBCO BRL), $20 \mathrm{mM}$ Tris- $\mathrm{HCl}, \mathrm{pH} 8.1,0.6$ $\mathrm{M} \mathrm{NaCl}, 12 \mathrm{mM} \mathrm{MgCl}_{2}, 12 \mathrm{mM} \mathrm{CaCl}_{2}$, and $2 \mathrm{mM}$ dAMP (to suppress phosphatase activity on the oligonucleotides). Aspergillus oryzae $S 1$ nuclease (Pharmacia), $50 \mathrm{mM}$ sodium acetate, $\mathrm{pH} 4.7,0.3 \mathrm{M} \mathrm{NaCl}$, and $10 \mathrm{mM}$ zinc acetate. Staphylococcus aureus (micrococcal) nuclease $S 7$ (Sigma), $20 \mathrm{mM}$ Tris- $\mathrm{HCl}, \mathrm{pH} 8.1,5 \mathrm{mM} \mathrm{MgCl}_{2}, 10 \mathrm{mM} \mathrm{CaCl}_{2}$, and $2 \mathrm{mM}$ dAMP. Phage $\lambda 5^{\prime}$-exonuclease (GIBCO BRL), 67 $\mathrm{mM}$ glycine- $\mathrm{KOH}, \mathrm{pH} 9.4,2.5 \mathrm{mM} \mathrm{MgCl} 2,0.05 \mathrm{mg} \mathrm{mL}^{-1}$ BSA. E. coli DNA polymerase I, large (Klenow) fragment (Pharmacia), $50 \mathrm{mM}$ Tris- $\mathrm{HCl}, \mathrm{pH} 7.5,10 \mathrm{mM} \mathrm{MgCl}, 1 \mathrm{mM}$ DTT, $50 \mu \mathrm{g} \mathrm{mL}^{-1}$ BSA. E. coli DNA polymerase I (GIBCO BRL), $50 \mathrm{mM}$ Tris- $\mathrm{HCl}$, pH 7.5, $10 \mathrm{mM} \mathrm{MgCl}_{2}, 1 \mathrm{mM}$ DTT, and $50 \mu \mathrm{g} \mathrm{mL}^{-1} \mathrm{BSA}$.

(iii) Chemical Nuclease Reagents: Phenanthroline-copper complex $\left[(\mathrm{OP})_{2} \mathrm{Cu}^{+}\right], 50 \mathrm{mM}$ Tris- $\mathrm{HCl}, \mathrm{pH} 7.5,2 \mathrm{mM} \mathrm{MgCl}_{2}$, $4.8 \mathrm{mM}$ 3-mercaptopropronic acid, $340 \mu \mathrm{M} 1,10$ phenanthroline (Sigma), and $80 \mu \mathrm{M} \mathrm{CuSO}_{4}$. The reaction was stopped by adding 2,9-dimethyl-1,10-phenanthroline (Sigma) to a final concentration of $2 \mathrm{mM}$. Iron(II)-EDTA,

\footnotetext{
${ }^{1}$ Abbreviations: ps, parallel-stranded; aps, antiparallel-stranded; ss, single-stranded; NMR, nuclear magnetic resonance; Tris, tris(hydroxymethyl)aminomethane; BSA, bovine serum albumin; DTT, dithiothreitol; EDTA, ethylenediaminetetraacetic acid; EGTA, ethylene glycol bis $(\beta$ aminoethyl ether)- $N, N, N^{\prime}, N^{\prime}$-tetraacetic acid.
} 

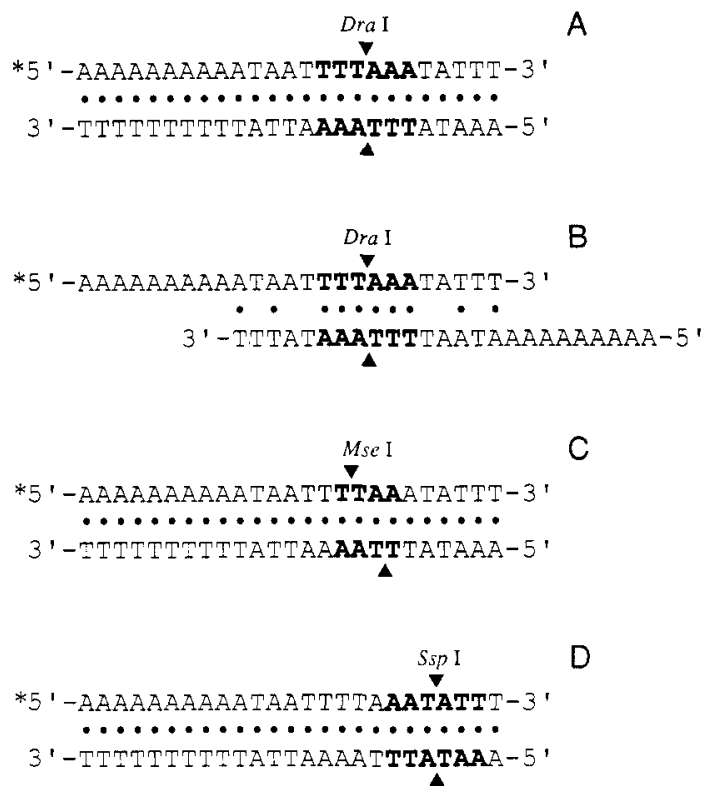

FIGURE 1: Restriction sites of aps oligonucleotides for DraI, MseI, and $S s p$ I endonucleases. The recognition sites of the enzymes are printed in bold letters. The triangles indicate the places where cutting takes place, and the Watson-Crick base pairs are shown by large dots. (A) aps-D 1*.D3 heteroduplex. (B) aps-D1*.D1 homoduplex with Dral cutting site and $10 \mathrm{bp}$. Other aps-D1-D1 homoduplexes with 14 bp at maximum but without a DraI restriction site are possible [see Figure 1C in Rippe et al. (1989)]. (C) aps-D1*.D3 heteroduplex with $M$ seI cutting site. (D) aps-D1*.D3 with SspI cutting site.

$2 \mathrm{mM} \mathrm{MgCl}, 1 \mathrm{mM}$ sodium ascorbate, $0.03 \% \mathrm{H}_{2} \mathrm{O}_{2}, 30 \mu \mathrm{M}$ $\mathrm{FeSO}_{4}$, and $60 \mu \mathrm{M}$ EDTA. Thiourea (Merck) to a final concentration of $20 \mathrm{mM}$ was added to stop the reaction.

(iv) Phage T4 DNA Ligase (Pharmacia): Fifty millimolar Tris- $\mathrm{HCl}, \mathrm{pH} 7.5,10 \mathrm{mM} \mathrm{MgCl}{ }_{2}, 20 \mathrm{mM}$ DTT, $5 \mu \mathrm{g} \mathrm{mL}^{-1}$ BSA, and $1 \mathrm{mM}$ ATP.

The enzymatic reactions were stopped by adding EDTA (in case of micrococcal nuclease, EGTA) to a final concentration of $20 \mathrm{mM}$ and heating the samples for $5 \mathrm{~min}$ at $60^{\circ} \mathrm{C}$. The amounts of enzyme are given in units as defined by the manufacturer. The oligonucleotides and their complexes were then examined by polyacrylamide gel electrophoresis under two conditions: (i) denaturing, with $20 \%$ polyacrylamide ( $5 \%$ cross-linking) gels, $8 \mathrm{M}$ urea, $90 \mathrm{mM}$ Tris-borate, $\mathrm{pH} 8.0,2$ $\mathrm{mM} \mathrm{NaEDTA}$, and $70^{\circ} \mathrm{C}$ (the samples were loaded in $40 \%$ formamide with $0.03 \%$ bromophenol blue and xylene cyanol as markers); and (ii) native, with $14 \%$ polyacrylamide (5\% cross-linking) gels, $90 \mathrm{mM}$ Tris-borate, $\mathrm{pH} 8.0,2 \mathrm{mM} \mathrm{MgCl}$, and $20^{\circ} \mathrm{C}$ (the samples were loaded in $15 \%$ Ficoll (Pharmacia) containing $0.03 \%$ bromophenol blue and xylene cyanol as markers).

\section{RESUlTS AND DISCUSSION}

Restriction Endonucleases. The ps and aps duplexes (with one ${ }^{32} \mathrm{P}$-labeled strand) were tested as substrates for the type II restriction endonucleases DraI (Purvis \& Mosley, 1983), MseI (Morgan, 1988), and SspI (Roberts, 1988). The recognition sites of these endonucleases with aps-D1*.D3 are shown in Figure 1A,C,D. The enzymes made double-stranded cuts with the aps duplexes, creating restriction fragments of the expected lengths. In the case of DraI, cleavage of the single-stranded (ss) D1* and D3* (the latter at a reduced rate) also appeared. A single-stranded activity has been reported for several restriction enzymes (e.g., HaeIII, MspI) and attributed to cleavage of temporarily existing double-stranded secondary structures (Nishigaki et al., 1985). Accordingly, the observed cutting with DraI of ss-D1* could be that of an aps transient homoduplex intermediate with a restriction site stabilized by the enzyme (Figure 1B). The previous observations that the ps constructs established with the $21-n t C$ series of oligonucleotides were susceptible to DraI (Ramsing \& Jovin, 1989) would appear to have been related to the same phenomenon. When the strands D2 and D4 needed to constitute the ps duplexes ps-D1*.D2 and ps-D3*.D4 were added, no more cutting with DraI appeared. Thus, the ps duplexes are resistant toward digestion with the restriction enzyme (Figure 2).

Incubations with $M s e I$ and $S s p I$ led to the same results. With $M$ seI, however, hardly any cleavage of the single oligonucleotide substrate was observed, although formation of a homoduplex with a $\mathrm{DraI}$ site should also potentiate cutting with this enzyme (Figure 1B,C). We ascribe this difference to a lower ability of $\mathrm{MseI}$ to stabilize the homoduplex intermediate, perhaps due to an effect of the sequences flanking the recognition site. In the case of $S s p I$, the activity with the aps substrate was also very low. The enzyme was tested in a control reaction with plasmid pBR 322 (10 units of SspI/ pmol of cutting site and $250 \mu \mathrm{M}$ DNA). The digestion was complete after $2 \mathrm{~h}$ of incubation at $25^{\circ} \mathrm{C}$. Therefore, we attribute the low activity of $S s p I$ with the oligonucleotides to the location of the cutting site at the very end of the apsD1*.D3 duplex.

Knowledge about the structures and reaction mechanisms of restriction enzymes originates mainly from studies with EcoRI that serves as a model system (McClarin et al., 1986). Type II restriction enzymes in general might act as dimers, in which each subunit is responsible for the cutting of one strand within the recognition sequence. The high nonspecific affinity for duplex DNA exhibited by several restriction enzymes suggests a mechanism according to which the enzyme binds first to a random DNA sequence and then translates along the DNA (Jack et al., 1982). Upon finding the right recognition sequence, the catalytic site of the enzyme becomes active and strand scission ensues. If this holds true for the three restriction enzymes examined here, one would expect two possible results with a ps substrate: (i) cutting only of the one strand of the ps duplex that has the recognition sequence in the right polarity; (ii) no cutting at all because the enzyme cannot bind to the ps duplex or binds only nonspecifically and is not able to exert its catalytic activity. The latter possibility would seem to apply. The specific interactions between the restriction enzymes tested and their respective substrates required to potentiate cleavage are not feasible with ps-DNA due to its different groove geometry (Pattabiraman, 1986; van de Sande et al., 1988; Ramsing \& Jovin, 1988).

Other Endo- and Exonucleases: DNase I and Exonuclease III. With $\mathrm{Mg}^{2+}$ and $\mathrm{Ca}^{2+}$ as metal cofactors, DNase I introduces single-stranded breaks into the B-DNA helix (Campbell \& Jackson, 1980). The enzyme cleaves near the $3^{\prime}$ end or the center of a DNA strand, but not, or only at low rates, near the 5' end (Lomonosoff et al., 1981; Drew, 1984). If present at high concentrations, DNase I is also able to degrade single-stranded DNA but at a rate reduced by about 4 orders of magnitude (Laskowski, 1971). The structure of the crystallized complex between the enzyme and B-DNA has been recently revealed (Suck et al., 1988). It has been shown that an exposed loop of DNase I binds in the minor groove of the DNA. This is consistent with the findings that conformational changes of the minor groove affect the cleavage rate. Sequences such as poly $(\mathrm{dA} \cdot \mathrm{dT})$ with its narrow minor groove show a decreased cutting rate with DNase I (Drew \& Travers, 1985). Besides the groove width, however, other 

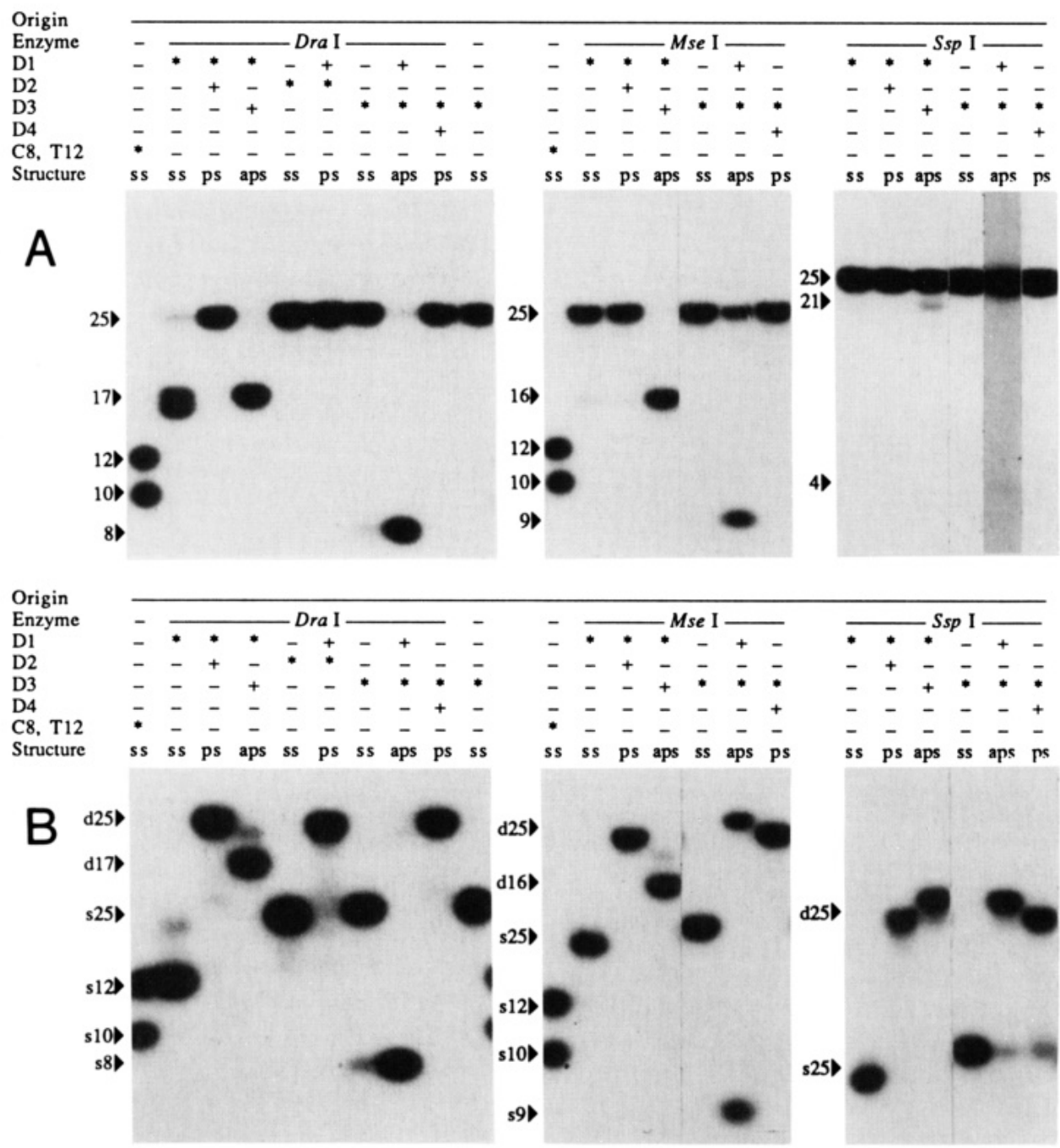

FIGURE 2: Digestion of given ${ }^{32} \mathrm{P}$-labeled oligonucleotides with $\mathrm{DraI}, \mathrm{MseI}$, and $\mathrm{Ssp \textrm {I }}$ restriction endonucleases. DNAs were incubated with DraI (2.5 units of DraI/pmol of cutting site and $40 \mu \mathrm{M}$ DNA for $13 \mathrm{~h}$ at $25^{\circ} \mathrm{C}$ in $20 \mu \mathrm{L}$ of restriction buffer), MseI ( 0.5 unit of $\mathrm{MseI} / \mathrm{pmol}$ of cutting site and $22 \mu \mathrm{M}$ DNA for $15 \mathrm{~h}$ at $25^{\circ} \mathrm{C}$ in $25 \mu \mathrm{L}$ of restriction buffer), and $S s p \mathrm{I}$ ( 2.4 units of $S s p \mathrm{I} / \mathrm{pmol}$ of cutting site and 20 $\mu \mathrm{M}$ DNA for $15 \mathrm{~h}$ at $25^{\circ} \mathrm{C}$ in restriction buffer at $\left.25^{\circ} \mathrm{C}\right)$. The unlabeled oligonucleotide was in slight excess (1:1.2-1:1.5). Two aliquots $(10 \mu \mathrm{L})$ of each sample were taken and stopped by addition of EDTA to a final concentration of $20 \mathrm{mM}$ and heating for $5 \mathrm{~min}$ at $60^{\circ} \mathrm{C}$. The samples were then run on (A) a $20 \%$ denaturing polyacrylamide gel at $70^{\circ} \mathrm{C}$ (the slot with aps-D1.D3* in the $S s p \mathrm{I}$ digest was overexposed to emphasize the 4-bp product) and (B) a $14 \%$ native polyacrylamide gel at $20^{\circ} \mathrm{C}$. The prefixes $\mathrm{s}$ and $\mathrm{d}$ on the references denote single- and double-stranded species, respectively. $C 8$ is the decanucleotide $d\left(\mathrm{AT}_{2} \mathrm{~A}_{3} \mathrm{~T}_{4}\right)$, and $\mathrm{T} 12$ is $\mathrm{d}(\mathrm{T})_{12}$.

structural features probably influence the activity of the enzyme, as, for example, the degree of DNA stiffness resisting bending (Suck et al., 1988).

As shown in Figure 3A DNase I reveals a very low level of activity of the enzyme with ps-D1*.D2* compared to that with aps-D1*.D3* (lanes 2 and 4). The same experiment was repeated at $37^{\circ} \mathrm{C}$ (Figure 3B). At this temperature, the ps duplex should be melted, and we find in fact that the activity of DNase I with both the ps and the aps substrates is similar. It follows that the difference in cleavage rate observed at 23 ${ }^{\circ} \mathrm{C}$ (Figure 3A) is due to fundamental distinctions in the helical conformations. The digestion of labeled aps-D2*.D4* was significantly inhibited in the presence of a 10 -fold excess of unlabeled ps-D3·D4, demonstrating that DNase I can bind to the ps duplex albeit with an affinity we have yet to determine (data not shown).

Exonuclease III from $E$. coli degrades a double-stranded DNA fragment processively by removing nucleotides from both $3^{\prime}$ ends until the substrate becomes single stranded and resistant to further digestion (Wu, 1985). In addition, the enzyme possesses a $3^{\prime}$-phosphatase, a RNase $\mathrm{H}$, and a endonuclease activity for apurinic and apyrimidinic sites, i.e., sites in double-stranded DNA where a purine or pyrimidine base has been cleaved from the sugar-phosphate backbone (Rogers \& Weiss, 1980). As shown in Figure 3C, the 3 -exonuclease activity was very low with the ps substrate as compared to that with the aps duplex or the ss-D3*. The susceptibility of the single-stranded substrate may be due to the transient aps secondary structure. A decreased rate of degradation was also reported for hairpin ps molecules (van de Sande et al., 1988).

Other Endo- and Exonucleases: Bal 31, S1 Nuclease, Micrococcal Nuclease (S7) and $\lambda$-Exonuclease. Nuclease Bal 31 contains a doule-strand-specific exonuclease activity that removes nucleotides from both ends and an activity for endonucleolytic degradation of single-stranded DNA (Legerski et al., 1977). The digestion by this enzyme was similar with the ps and aps duplexes, but preferred cutting sites were only observed with aps-D1*.D3* and ss-D1* (Figure 4A).

$S 1$ nuclease degrades selectively single-stranded DNA (Vogt, 1973). The enzyme exhibits a 75000 times higher activity with single-stranded DNA as opposed to doublestranded DNA (Wiegand et al., 1975). In addition, an activity for non-B-form duplexes such as cruciforms (Lilley, 1980) and junctions between B- and Z-DNA (Singleton et al., 1982) has 


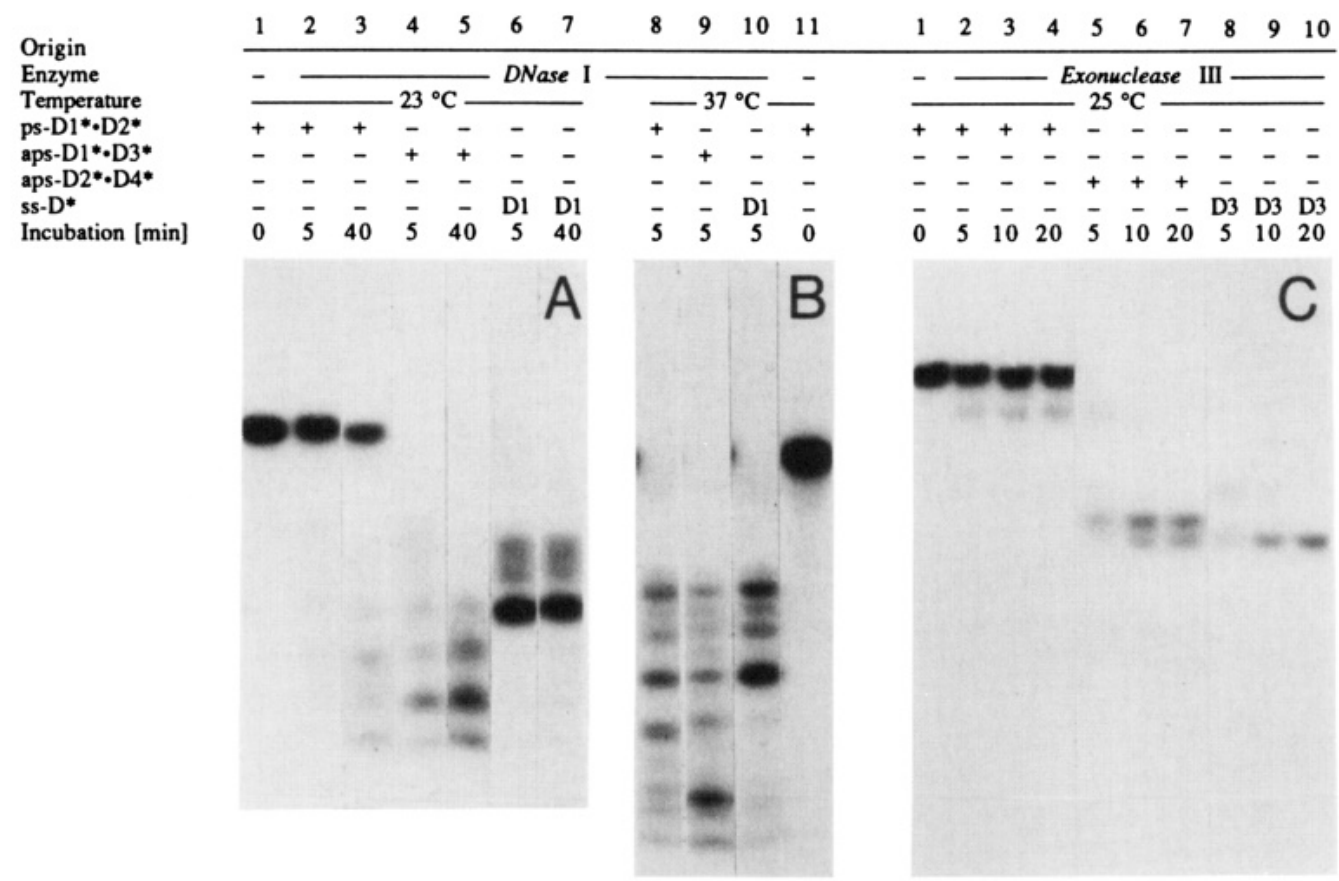

FIGURE 3: Digestion with DNase I and exonuclease III. (A) DNase I: Incubation of 8 units of DNase I/nmol of nucleotide and $10 \mu \mathrm{M}$ DNA in $90 \mu \mathrm{L}$ of reaction buffer at $23^{\circ} \mathrm{C}$ for given time intervals; $14 \mu \mathrm{L}$ of each sample was run on a denaturing gel. (B) DNase I: Incubation of 8 units of DNase $\mathrm{I} / \mathrm{nmol}$ of nucleotide and $10 \mu \mathrm{M}$ DNA in $90 \mu \mathrm{L}$ of reaction buffer at $37^{\circ} \mathrm{C}$ for 5 min; $14 \mu \mathrm{L}$ of each sample was run on a denaturing gel. (C) Exonuclease III: 1.3 units/nmol nucleotide, $10 \mu \mathrm{M}$ DNA in $100 \mu \mathrm{L}$ of reaction buffer at $25^{\circ} \mathrm{C}$ for given time intervals; $10 \mu \mathrm{L}$ of each sample was run on a denaturing gel.

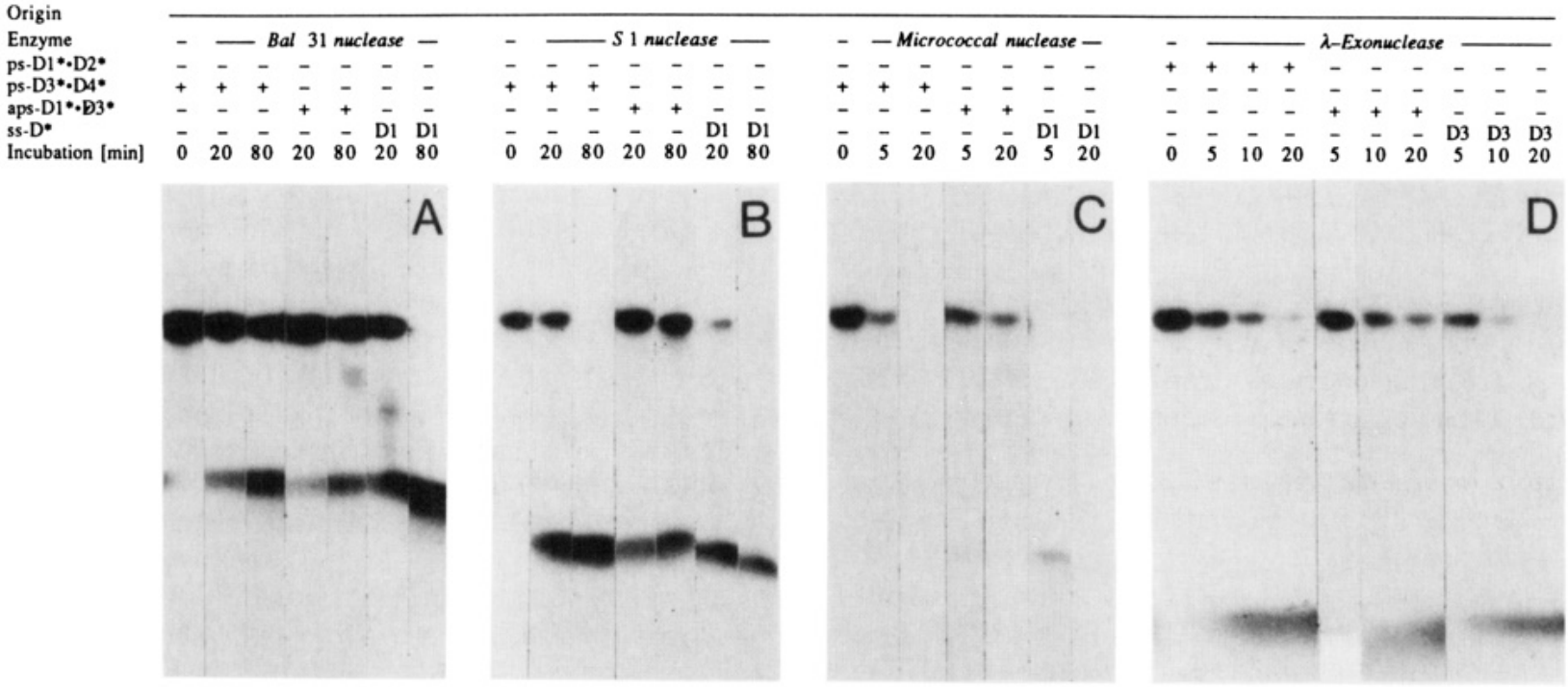

FIGURE 4: Digestion with Bal 31, $S 1$ nuclease, micrococcal nuclease (S7), and $\lambda$-exonuclease. (A) Bal $31: 0.01$ unit/nmol of nucleotide and $5 \mu \mathrm{M}$ DNA in $100 \mu \mathrm{L}$ of reaction buffer; $15 \mu \mathrm{L}$ of each sample was run on a denaturing gel. (B) $S 1$ nuclease: 42 units/nmol of nucleotide and $5 \mu \mathrm{M}$ DNA in $100 \mu \mathrm{L}$ of reaction buffer; $11 \mu \mathrm{L}$ of each sample was run on a denaturing gel. (C) Micrococcal nuclease: 0.002 unit/nmol of nucleotide and $10 \mu \mathrm{M}$ DNA in $50 \mu \mathrm{L}$ of reaction buffer; $7.5 \mu \mathrm{L}$ of each sample was run on a denaturing gel. (D) $\lambda$-exonuclease: 1.5 units/nmol of nucleotide and $5 \mu \mathrm{M}$ DNA in $100 \mu \mathrm{L}$ of reaction buffer; $15 \mu \mathrm{L}$ of each sample was run on denaturing gel.

been reported. $S 1$ shows no base recognition pattern, seeming to need only exposed phosphodiester bonds (like those in a loop) that are not part of a double helix, i.e., where the two sugar-phosphate strands protect each other. At the ends of the duplex, single-strand attack by $S 1$ also occurs, probably due to fraying of the ends (Drew, 1984). Therefore, the slightly increased activity of $S 1$ with the ps molecules (Figure 4B) might be due mainly to digestion at the ends. The lack of detectable specific cutting products indicates that cutting of internal single-stranded regions within the duplexes is unlikely.

Like $S 1$, micrococcal nuclease prefers a single-stranded substrate, but also exhibits exonuclease and endonuclease activities (Drew, 1984). With double-stranded DNA as a substrate, micrococcal nuclease cleaves preferentially regions of low helix stability, as, for example, in alternating dA.dT. This feature can be explained by either the formation of a single-stranded intermediate before cutting or by the higher potential of these regions to adopt other local DNA structures. Bending or twisting of the B-DNA axis or opening of the major or minor groove might be necessary for optimal binding and cutting of micrococcal nuclease (Flick et al., 1986). The enzyme demonstrated a somewhat higher activity with the ps than with the aps substrate. This may be in part a consequence of the lower stability of the ps duplex (Rippe et al., 1989; Ramsing et al., 1989) which is accompanied by increased fraying of the ends and a higher ability to show transiently melted regions within the duplex. However, the activity of 


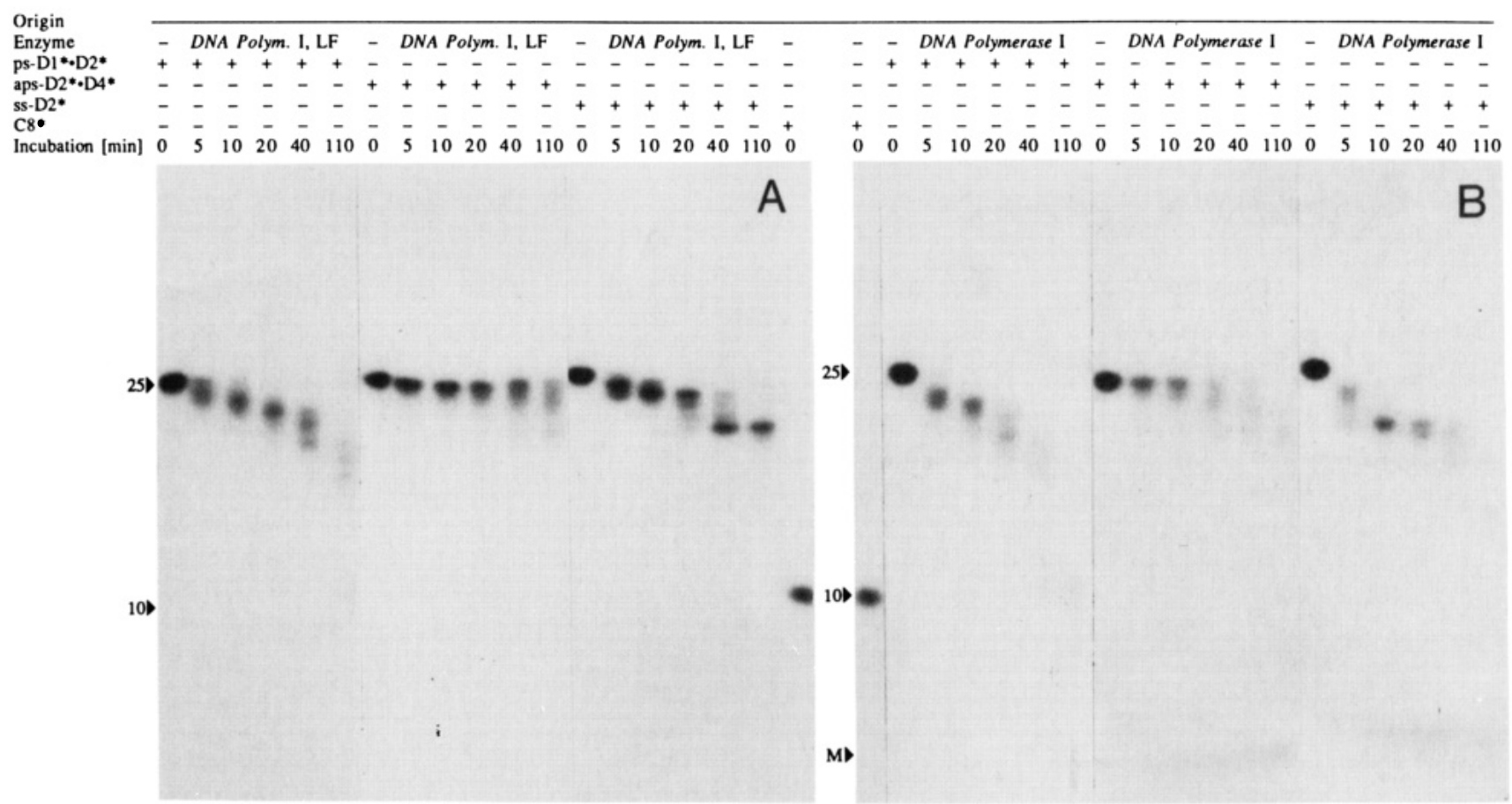

FIGURE 5: Digestion with large fragment of DNA polymerase I (Klenow fragment) and DNA polymerase I. The position where the mononucleotides appear is indicated by an M. (A) Large fragment of DNA polymerase I: 3.6 units/nmol of nucleotide and $10 \mu \mathrm{M}$ DNA in $50 \mu \mathrm{L}$ of reaction buffer; $7.5 \mu \mathrm{L}$ of each sample was run on a denaturing gel. (B) DNA polymerase I: 2.4 units/nmol of nucleotide and $10 \mu \mathrm{M}$ DNA in 50 $\mu \mathrm{L}$ of reaction buffer; $7.5 \mu \mathrm{L}$ of each sample was run on a denaturing gel.

micrococcal nuclease as well as that of $S 1$ was highest in the case of the ss-D1* substrate, which probably forms an aps homoduplex with single-stranded terminal segments. The ps-D3*.D4* and aps-D1*D3* DNAs were more resistant to degradation by the single-stranded-specific nucleases (parts $\mathrm{B}$ and $\mathrm{C}$ of Figure 4 after 20 -min incubation with $S 1$ and 5 -min incubation with micrococcal nuclease, respectively), indicating that both combinations form duplex structures. The samples of the $S 1$ digest and the micrococcal nuclease digest were also electrophoresed on a native gel to verify that the ps duplex had formed under the conditions used in the reaction (data not shown).

Neither $S 1$ nor micrococcal nuclease showed a preferred cutting site with the ps duplex, implying that regions of exposed phosphates within the ps duplex do not exist.

$\lambda$-Exonuclease from the bacteriophage $\lambda$ processively removes mononucleotides from the $5^{\prime}$ termini of double-stranded DNA, the preferred substrate. Single-stranded DNA is a poor substrate if it remains in a random coiled state. However, the ss activity of the enzyme increases with the inverse of the chain length and may reach $10 \%$ of the rate of digestion of double-stranded DNA as the $5^{\prime}$ ends become more easily accessible in short polynucleotides (Sriprakash et al., 1974). The results of digestion with $\lambda$-exonuclease are similar to those of the two single-strand-specific nucleases $S 1$ and micrococcal nuclease (Figure 4D). The activity with the ps substrate is higher than that of the aps duplex, but both are degraded at a lower rate than ss-D3*, which apparently again forms an aps secondary structure.

E. coli DNA Polymerase I and Its Large Fragment (Klenow Fragment). E. coli DNA polymerase I is a multifunctional enzyme with a polymerase activity, a $3^{\prime} \rightarrow 5^{\prime}$ exonuclease activity (for ss-DNA and frayed or non-base-paired ends of duplexes), and a $5^{\prime} \rightarrow 3^{\prime}$ exonuclease activity (for base-paired ends of duplexes). Its large (Klenow) fragment lacks the $5^{\prime}$ $\rightarrow 3^{\prime}$ exonuclease activity (Kornberg, 1980). The structure of the complex between $E$. coli DNA polymerase I large fragment and B-DNA has been recently elucidated (Freemont et al., 1988). Comparing the ps and the aps duplexes as substrates for DNA polymerase I (Figure 5B) and its large fragment (Figure 5A), we note a higher $3^{\prime} \rightarrow 5^{\prime}$ activity with the ps molecules, probably reflecting their reduced stability. That is, the higher activity found with the ps substrate may be attributable to digestion of frayed ends, inasmuch as the $3^{\prime} \rightarrow 5^{\prime}$ activity is specific for unpaired bases (Kornberg, 1980).

The ps-D1*.D2* duplex, however, showed no degradation (generation of mononucleotides) that could be assigned to the $5^{\prime} \rightarrow 3^{\prime}$ activity present only in DNA polymerase I. In Figure $5 \mathrm{~B}$, the smeared band of mononucleotides denoted with an $\mathrm{M}$ is only visible in the case of aps-D2*.D4* and ss-D2* as substrates. Because of the $5^{\prime}$ labeling, these mononucleotides should originate from the $5^{\prime} \rightarrow 3^{\prime}$ nuclease activity and are consistently absent in the degradation with Klenow fragment.

Chemical Reagents with Nuclease Activity. The 1,10phenanthroline-copper complex $\left[(\mathrm{OP})_{2} \mathrm{Cu}^{+}\right]$is an artificial nuclease with hydrogen peroxide as a coreactant. The reagent generates hydroxyl radicals that cleave B-DNA by oxidation of the deoxyribose near the binding site of the complex in the minor groove (Sigman, 1986; Kuwabara et al., 1986). The reactivity of $(\mathrm{OP})_{2} \mathrm{Cu}^{+}$with B-DNA is sequence dependent. That is, different sequences show different hyperreactive sites because of local variations in the minor groove conformation that influence binding of the complex (Veal \& Rill, 1988); left-handed Z-DNA or single-stranded DNA incapable of forming secondary structures are not cleaved (Marshall et al., 1981; Pope \& Sigman, 1984), while a DNA-RNA hybrid in the A conformation with the characteristic shallow minor groove is digested at only one-third the rate of B-DNA (Sigman, 1986).

As shown in Figure $6 \mathrm{~A},(\mathrm{OP})_{2} \mathrm{Cu}^{+}$degraded ps-DNA and aps-DNA at approximately the same rate but showed preferred cutting sites only with the aps-D1*.D3* and the ss-D2*, obviously due to the formation of antiparallel secondary structures. The lack of preferred cutting sites with the ps substrate 


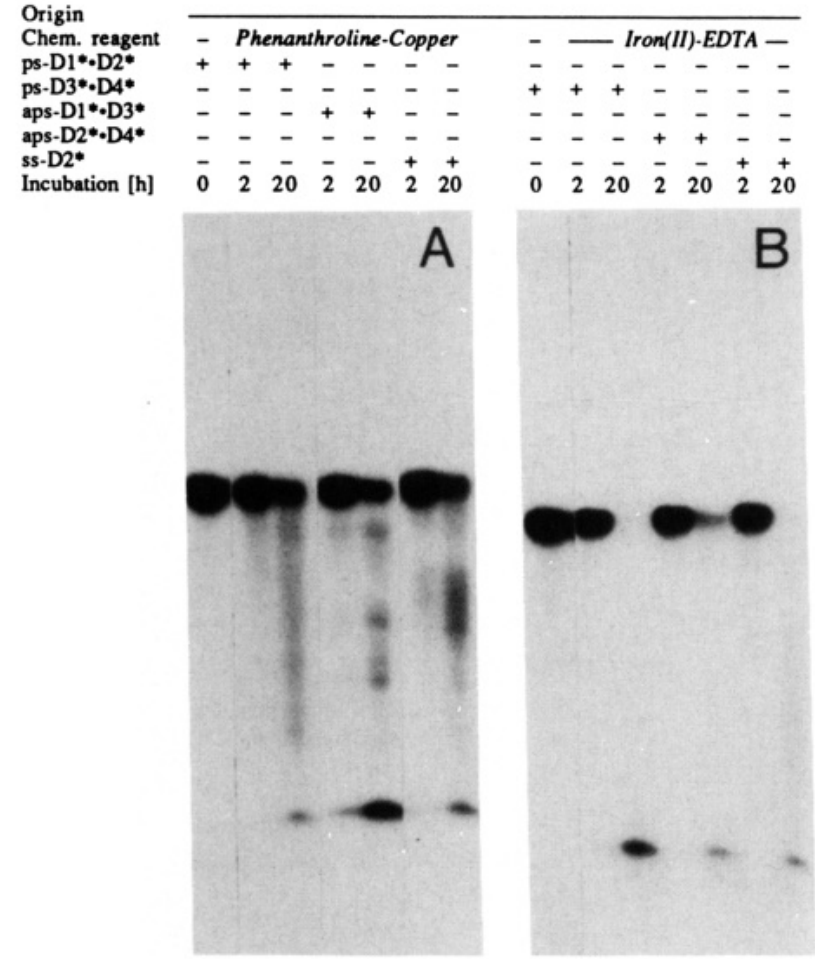

FIGURE 6: Degradation by chemical reagents with nuclease activity. (A) $(\mathrm{OP}){ }_{2} \mathrm{Cu}^{+}:\left[(\mathrm{OP})_{2} \mathrm{Cu}^{+}\right] /[$nucleotide] $=13$. DNA concentration was $6 \mu \mathrm{M}$ in $30 \mu \mathrm{L}$ of reaction buffer; $9 \mu \mathrm{L}$ of each sample was run on a denaturing gel. (B) Iron(II)-EDTA: [iron(II)-EDTA]/[nucleotide] $=5$ and $6 \mu \mathrm{M}$ DNA in $50 \mu \mathrm{L}$ of reaction buffer; $9 \mu \mathrm{L}$ of each sample was run on a denaturing gel.

$\begin{array}{llllllll}\text { Enzyme } & - & & \text { T4 } & \text { DNA Ligase } & - \\ \text { ps-D3*·D4* } & - & + & + & - & - & - & - \\ \text { aps-D2*•D4* } & - & - & - & + & + & - & - \\ \text { ss-D4* } & + & - & - & - & - & + & + \\ \text { Incubation [h] } & 0 & 1 & 20 & 1 & 20 & 1 & 20\end{array}$

Origin

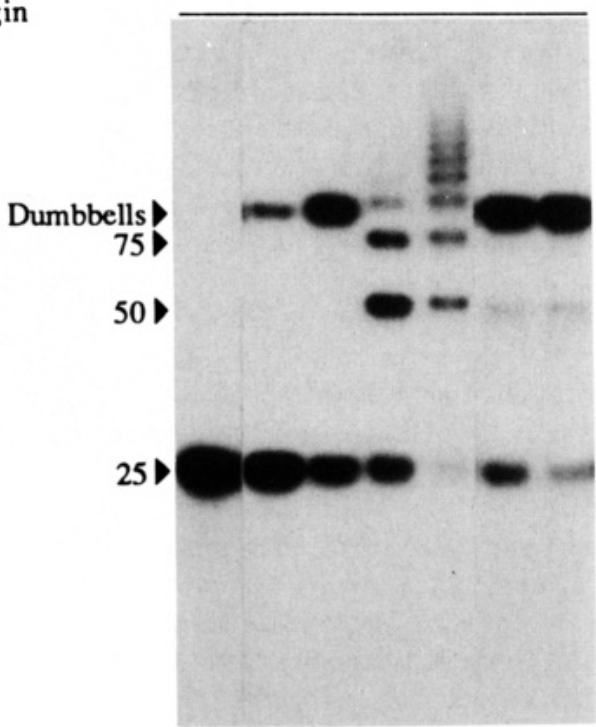

FIGURE 7: Blunt-end ligation of ${ }^{32} \mathrm{P}$-labeled oligonucleotides and their ps and aps duplexes. 2 units of T4 DNA ligase/pmol of $5^{\prime}$ ends and $10 \mu \mathrm{M}$ DNA were incubated in $50 \mu \mathrm{L}$ of ligation buffer; $9 \mu \mathrm{L}$ of each sample was run on a denaturing gel.

in both the (OP) ${ }_{2} \mathrm{Cu}^{+}$digest and the $\mathrm{Bal} 31$ digest (see above) is indicative of a uniform chemical environment in both grooves of the ps helix (Figure 9).

Iron(II)-EDTA is another chemical reagent with nuclease activity that was tested with ps-D3*.D4*, aps-D2*.D4*, and ss-D2* (Figure 6B). Like (OP) ${ }_{2} \mathrm{Cu}^{+}$, the iron(II)-EDTA

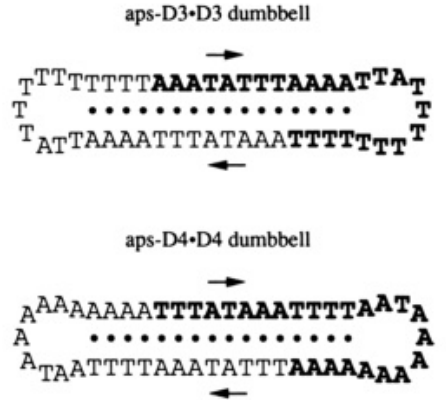

FIGURE 8: Dumbbells aps-D3.D3 and aps-D4-D4 formed during the ligation experiment. One strand is printed in bold letters. The arrows point in the $3^{\prime}$ direction, and the Watson-Crick base pairs are shown by large dots.

\begin{tabular}{|c|c|c|c|}
\hline enzyme activity ${ }^{a}$ & ps-DNA & aps-DNA & ss-DNA $^{b}$ \\
\hline \multicolumn{4}{|l|}{ restriction enzymes } \\
\hline DraI & - & +++ & ++ \\
\hline MseI & - & +++ & - \\
\hline SspI & - & + & - \\
\hline \multicolumn{4}{|l|}{ DNA nucleases } \\
\hline DNase I & - & +++ & +++ \\
\hline exonuclease III $^{c}$ & - & ++ & +++ \\
\hline Bal 31 nuclease & + & $t^{d}$ & $++^{d}$ \\
\hline$S 1$ nuclease & ++ & + & +++ \\
\hline micrococcal nuclease $(S 7)$ & ++ & + & +++ \\
\hline$\lambda$-exonuclease & + & ++ & +++ \\
\hline $\begin{array}{l}\text { DNA polymerase I, large } \\
\text { fragment }^{e}\end{array}$ & +++ & ++ & +++ \\
\hline \multicolumn{4}{|l|}{ DNA polymerase I } \\
\hline $3^{\prime} \rightarrow 5^{\prime}$ activity & +++ & ++ & +++ \\
\hline $5^{\prime} \rightarrow 3^{\prime}$ activity & - & + & + \\
\hline \multicolumn{4}{|l|}{ chemical reagents } \\
\hline phenanthroline-copper & + & $+^{d}$ & $+^{d}$ \\
\hline iron(II)-EDTA & + & + & + \\
\hline \multicolumn{4}{|l|}{ other DNA processing enzymes } \\
\hline $\begin{array}{l}\text { T4 DNA ligase, blunt end } \\
\text { ligation }\end{array}$ & - & +++ & +++ \\
\hline T4 DNA kinase $f$ & +++ & +++ & +++ \\
\hline
\end{tabular}

${ }^{a}$ Relative enzyme activities: +++ , very high; ++ , high; + , moderate; -, none or very low. ${ }^{b}$ The ss-DNA apparently also formed aps secondary structures such as aps homoduplexes with mismatches. ${ }^{c}$ Similar results were found also with the ps and aps hairpins (van de Sande et al., 1988). ${ }^{d}$ Bal 31 and the phenanthroline-copper complex degraded ps-DNA and aps-DNA with approximately the same rate but showed preferred cutting sites only with aps-DNA. 'No polymerase activity with ps-DNA according to Germann et al. (1988). ${ }^{f}$ Determined with the ps and aps hairpins (van de Sande et al., 1988).

complex generates hydroxyl radicals from hydrogen peroxide, but it does not bind to the DNA. Therefore, cutting takes place almost equally at every backbone position of random B-DNA sequences (Tullius \& Dombrowski, 1985; Burkhoff \& Tullius, 1988). Ascorbate is present to reduce the iron(III) product of the reaction back to iron(II). The reaction with iron(II)-EDTA revealed no significant differences between the three substrates (Figure 6B). This result is in agreement with the expectation that the very small, nonspecifically reacting, freely diffusable hydroxyl radicals cannot distinguish between the differences in the ps and the aps duplex structures.

Blunt-End Ligation with Phage T4 DNA Ligase. As shown in Figure 7, the aps-D2.D4* duplex was a substrate for phage T4 DNA ligase, showing the expected ligation ladder of which the 50 -mer, the 75 -mer, and the 100 -mer can be identified easily (Figure 7). The ligation of individual oligonucleotides D3* and D4* and of ps-D3*.D4*, however, stopped with a product between the 75 -mer and the 100 -mer of the apsD2*.D4* ligation. We attribute this result to the formation of dumbbells involving two strands of either D3* or D4* with 


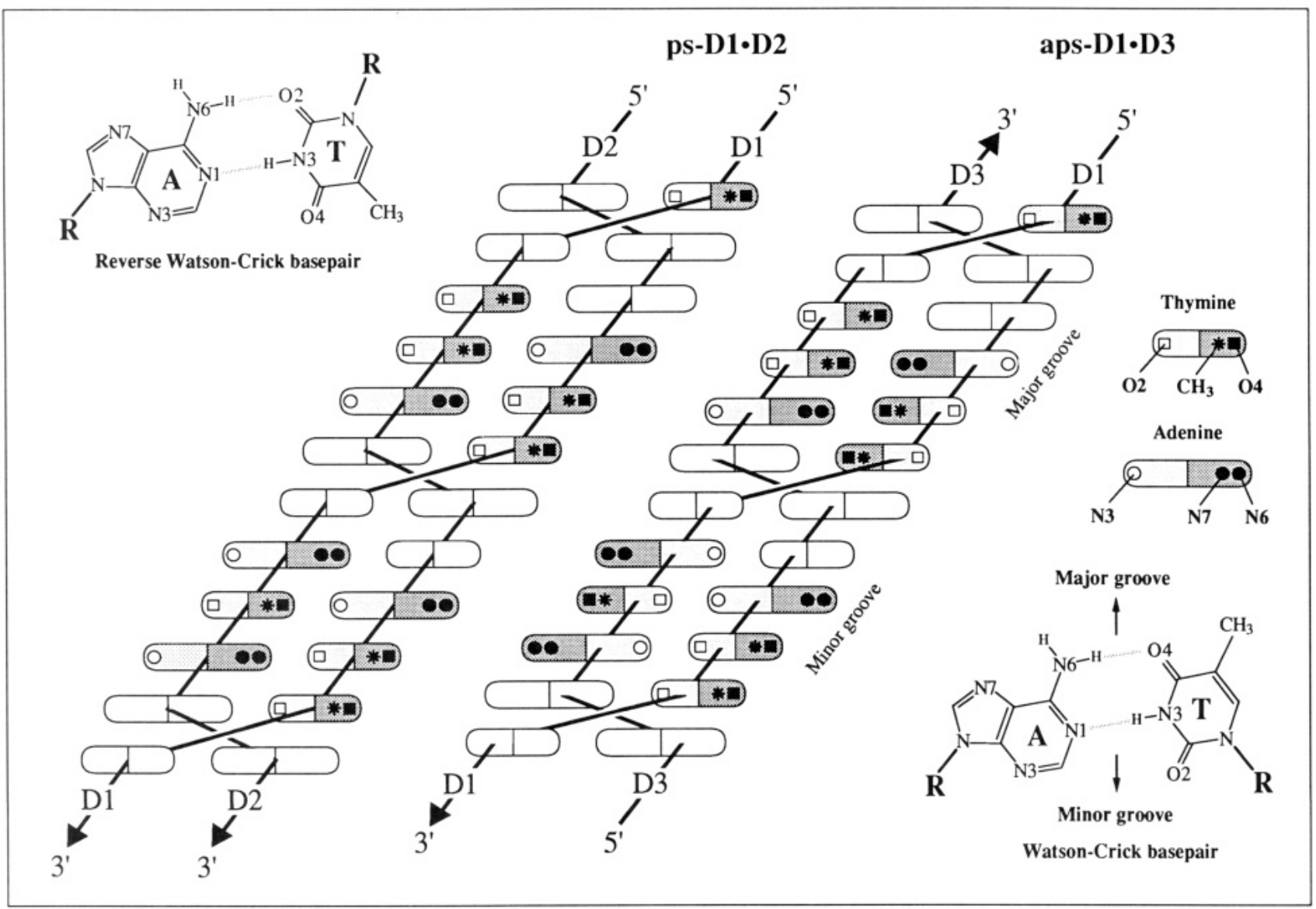

FIGURE 9: Schematic view of the last 12 bp at the $3^{\prime}$ end of ps-D1·D2 and the aps-D1·D3 laid out in a cylindrical projection. The sugar-phosphate backbone is shown as a continuous line with the given polarity. The empty base symbols indicate that the nucleotides in those positions are oriented more or less perpendicular to the image plane. Note that the two grooves of ps-DNA cannot be distinguished a priori. That is, the functional groups of both bases project equally into both grooves. The ps helix is also slightly more extended according to model calculations.

a $16 \mathrm{bp}$ long stem region and two loops consisting of 9 bases. The aps-D3-D3 dumbbell and the aps-D4.D4 dumbbell are shown in Figure 8. The precursors for these dumbbells, i.e., the duplexes originating from hairpins formed by intramolecular hydrogen bonding, can be present only at very low concentrations, since in the companion paper (Rippe et al., 1989, Figure 2B) no higher order structures of the single strands could be detected under the conditions maximally favoring duplex formation. Thus, the ligation itself provides the mechanism leading to the quantitative conversion to the covalently closed dumbbell structures. From a comparison of the results of the ligation experiment of ps-D3*.D4* and ss-D4* after $1 \mathrm{~h}$ of incubation (Figure 7), it is apparent that dumbbell formation is delayed in the case of the ps duplex. This is to be expected because of the higher activation energy of the reaction needed for the dissociation of the ps duplex. Except for the dumbbell band, no other products were perceived in the case of the ps-D3*.D4* duplex. Therefore, we assume that blunt-end ligation with ps duplexes is not possible, a result in agreement with the observations made previously with the 21-nt series of ps linear oligonucleotides (Ramsing \& Jovin, 1988).

\section{CONCLUding Remarks}

The substrate properties of ps-DNA (a summary is given in Table I) are consistent with the models presented to date for the ps helix (van de Sande et al., 1988; Ramsing \& Jovin, 1988). The characteristic features of ps-DNA are the parallel orientation of both strands with two equivalent grooves, reverse Watson-Crick base pairing, and a reduced thermodynamic stability upon heating (van de Sande et al., 1988; Ramsing et al., 1989; Rippe et al., 1989; see also Figure 9). We interpret our data in terms of these properties as follows: (i) The results with the restriction endonucleases (DraI, MseI, $S s p$ I), DNase I, exonuclease III, and the $5^{\prime} \rightarrow 3^{\prime}$ activity of DNA polymerase I are indicative of a duplex structure that is distinctly different from that of B-DNA. All these enzymes require a double-stranded substrate and therefore are more likely to reveal differences between the ps and aps duplexes than the single-strand-specific enzymes. (ii) The absence of preferred cutting sites with $\mathrm{Bal} 31$ and the 1,10phenanthroline-copper complex $\left[(\mathrm{OP})_{2} \mathrm{Cu}^{+}\right]$in the case of the ps substrate but not with the aps molecules supports the model of a ps helix that lacks the distinction between a major and a minor groove (compare Figure 9). (iii) The results with $S 1$, micrococcal nuclease, DNA polymerase I ( $3^{\prime} \rightarrow 5^{\prime}$ activity), and its large fragment can be explained by the reduced stability of the ps duplex.

The present study shows that ps-DNA can be recognized by several DNA processing enzymes, e.g., $\lambda$-exonuclease, Bal 31 , and DNA polymerase I, raising the distinct possibility that this new DNA structure is of biological relevance.

\section{ACKNOWLEDGMENTS}

We thank G. Heim for excellent technical assistance and Niels B. Ramsing for many valuable discussions.

\section{REFERENCES}

Burkhoff, A. M., \& Tullius, T. D. (1988) Nature 331, 455-457.

Campbell, V. W., \& Jackson, D. A. (1980) J. Biol. Chem. 255, 3726-3735. 
Drew, H. R. (1984) J. Mol. Biol. 176, 535-557.

Drew, H. R., \& Travers, A. A. (1985) Nucleic Acids Res. 13, 4445-4467.

Flick, J. T., Eisenberg, J. C., \& Elgin, S. C. R. (1986) J. Mol. Biol. 190, 619-633.

Freemont, P. S., Friedman, J. M., Beese, L. S., Sanderson, M. R., \& Steitz, T. A. (1988) Proc. Natl. Acad. Sci. U.S.A. $85,8924-8928$.

Germann, M. W., Kalish, B. W., \& van de Sande, J. H. (1988) Biochemistry 27, 8302-8306.

Jack, W. E., Terry, B. J., \& Modrich, P. (1982) Proc. Natl. Acad. Sci. U.S.A. 79, 4010-4014.

Kornberg, A. (1980) DNA Replication, Freeman, San Francisco.

Kuwabara, M., Yoon, C., Goyne, T., Thederahn, T., \& Sigman, D. S. (1986) Biochemistry 25, 7401-7408.

Laskowski, M. (1971) Enzymes (3rd Ed.) 4, 289-311.

Legerski, R. J., Gray, H. B., Jr., \& Robberson, D. L. (1977) J. Biol. Chem. 252, 8740-8746.

Lilley, D. M. F. (1980) Proc. Natl. Acad. Sci. U.S.A. 77, 6468-6472.

Lomonosoff, G. P., Butler, P. J. G., \& Klug, A. (1981) J. Mol. Biol. 149, 745-760.

Marshall, L. E., Graham, D. R., Reich, K. A., \& Sigman, D. S. (1981) Biochemistry 20, 244-250.

McClarin, J. A., Frederick, C. A. Wang, B.-C., Greene, P. G., Boyer, H. W., Grable, J., \& Rosenberg, J. M. (1986) Science 234, 1526-1541.

Morgan, R. D. (1988) Nucleic Acids Res. 16, 3104.

Nishigaki, K., Kaneko, Y., Wakuda, H., Husimi, Y., \& Tanaka, T. (1985) Nucleic Acids Res. 16, 5747-5760.
Pattabiraman, N. (1986) Biopolymers 25, 1603-1606.

Pope, L. E., \& Sigman, D. S. (1984) Proc. Natl. Acad. Sci. U.S.A. 81, 3-7.

Purvis, I. J., \& Mosley, B. E. B. (1983) Nucleic Acids Res. $11,5467-5474$.

Ramsing, N. B., \& Jovin, T. M. (1988) Nucleic Acids Res. 16, 6659-6676.

Ramsing, N. B., Rippe, K., \& Jovin, T. M. (1989) Biochemistry (first of three papers in this issue).

Rippe, K., Ramsing, N. B., \& Jovin, T. M. (1989) Biochemistry (second of three papers in this issue).

Roberts, R. J. (1988) Nucleic Acids Res. 16, r271-r313.

Rogers, S. G., \& Weiss, B. (1980) Methods Enzymol. 65, 201-211.

Sigman, D. S. (1986) Acc. Chem. Res. 19, 180-186.

Singleton, C. K., Klysik, J., Stirdivant, S. M. \& Wells, R. D. (1982) Nature 299, 312-316.

Sriprakash, K. S., Lundh, N., Moo-On Huh, Martin, \& Radding, C. M. (1975) J. Biol. Chem. 250, 5438-5445.

Suck, D., Lahm, A., \& Oefner, C. (1988) Nature 332, 464-468.

Tullius, T. D., \& Dombrowski, B. A. (1985) Science 241, 551-557.

van de Sande, J. H., Ramsing, N. B., Germann, M. W., Elhorst, W., Kalisch, B. W., v. Kitzing, E., Pon, R. T., Clegg, R. M., \& Jovin, T. M. (1988) Science 241, 551-557.

Veal, J. M., \& Rill, R. L. (1988) Biochemistry 27, 1822-1827.

Vogt, V. M. (1973) Eur. J. Biochem. 33, 192-200.

Wiegand, R. C., Godson, G. N., \& Radding, C. M. (1975) J. Biol. Chem. 250, 8848-8855.

Wu, C. (1985) Nature 317, 84-87. 